\title{
VERNADSKY'S NOTIONS ON THE BIOSPHERE AND THEIR POSITIONS IN THE RECENT THEORY OF LITHOLOGY V.Kh. Gevorkian
}

\section{УЧЕНИЕ В.И. ВЕРНАДСКОГО О БИОСФЕРЕ И ЕГО РОЛЬ В СОВРЕМЕННОЙ ТЕОРЕТИЧЕСКОЙ ЛИТОЛОГИИ (К 140-ЛЕТИЮ СО ДНЯ РОЖДЕНИЯ) В.Х. Геворкьян}

Some discussive positions of the Vernadsky's ideas about biosphere are considered: the constant amount of alive matter, geological history of the Earth, biological and biochemical role of backterial microflora sedimentation. For the very first time, it is shown that the Vernadsky's ideas is very proved by the necessity of ideas by Vernadsky.

Kay words: biosphere, backterial microflora, gas, backterial microflora.

Рассмотрены некоторые спорные положения учения В.И. Вернадского о биосфере. В частности, о постоянстве массы живого вещества, связи климатических условий с историей геологического развития Земли, биогеохимической роли бактериальной микрофлоры в осадкообразовании. На основе новых данных, полученных главным образом в результате проведенных морских геологических исследований, доказывается концептуальная необходимость идей В.И. Вернадского.

Ключевые слова: биосфера, живое вещество, газовая компонента, бактериальная микрофлора.

Книгу «Химическое строение биосферы Земли и ее окружения» [4] В.И. Вернадский называл «главной книгой моей жизни». В ней доказывается, что явление жизни на Земле является мощным геологическим фактором, которому принадлежит решающая роль в геологической истории развития планеты и без учета которого ряд геологических явлений объяснить весьма затруднительно.

В.И. Вернадский приступил к работе над книгой в весьма зрелом возрасте - ему было 72 года. Он был мировой величиной, действительным членом многих академий наук, основоположником таких направлений в геологической науке, как геохимия, биогеохимия, радиогеохимия. Однако В.И. Вернадский считал, что изучение биосферы - главное дело его жизни, основной вклад в науку.

Учение о биосфере - это не гипотеза и не теория. Это комплекс научных дисциплин, объединённых изучением воздействия живого вещества как геологического фактора. В настоящее время есть все основания включить в это учение результаты геоэкологических исследований, биогенного осадконакопления, биогенного рудогенеза, а также ряда смежных дисциплин, таких как климатология, биология растительного и животного мира.

Отметим, что «живое вещество», по В.И. Вернадскому, «есть совокупность живых организмов. Это не что иное, как научное, эмпирическое обобщение всем известных и легко и точно наблюдаемых бесчисленных, эмпирически бесспорных фактов» [4, с. 324]. В основе учения о биосфере лежит биогеохимия [4, с. 328]. «Современная стадия, геологически переживаемая биосферой» - это ноосфера.

К понятию биосфера и ее роли в геологической истории Земли В.И. Вернадский подходил фундаментально и весьма последовательно, оперируя огромным количеством фактического материала различных областей естествознания. Основным критерием в оценке значимости используемого материала являлась его «эмпирическая основа». Как отмечал сам В.И. Вернадский, он не «принимал теоретические построения и гипотезы, лишенные этой основы». «Стоя на эмпирической почве, я буду и здесь оставаться на ней и не буду входить, поскольку это возможно, в область научных гипотез и научных теорий» $[4$, с. 16].

Начало научной деятельности В.И. Вернадского связано с его исследованиями в минералогии и кристаллографии. Вероятно, он был первым исследователем, полагавшим, что вода и газы - это особое состояние минералов. Изучение парагенетических ассоциаций в минералах послужило основой геохимии как нового научного направления. Будучи председателем ученого совета при Министерстве земледелия, В.И. Вернадский проводит исследования по изучению роли живого вещества с геохимической точки зрения. Им публикуются очерки о биосфере, о живом веществе. В монографии «Биосфера»[5], изданной в 1926 г., впервые дается четкое определение понятия биосфера. Эта книга, в значительно более полном виде, была переиздана на французском языке в 1929 г. в Пари- 
же [31]. И это направление становится главным в деятельности исследователя. Итогом многолетней работы явилась указанная монография, которая была опубликована только в 1965 г., через 17 лет после кончины ее автора.

По представлениям В.И. Вернадского, биосфера - «одна из многих других» [4, с. 52] геологическая оболочка Земли, «в ней господствуют проявления живого вещества» [4, с. 34], «это среда нашей жизни» [4, с. 63]. «Живые организмы являются функцией биосферы и теснейшим образом материально и энергетически с ней связаны, являются огромной геологической силой, ее определяющей» [4, с. 52]. «Живое вещество по весу составляет ничтожную часть планеты - тонкая пленка жизни» [4, с. 325]. Но «биогенные породы (т.е. созданные живым веществом) составляют огромную часть ее (Земли) массы» [4, с. 325]. Однако роль живого вещества в жизни планеты значительно шире - это колоссальная буферная система, уравновешивающая и стабилизирующая взаимодействия между внутренними и внешними геологическими сферами Земли. Этим и определяется планетная роль живого вещества [4, с. 151].

Проблема биосферы и оценка ее роли в геологической истории Земли, разрабатываемая В.И. Вернадским с конца 20-х годов прошлого столетия и суммированная в его монографии, не была воспринята советской геологической наукой. Ф.Т. Яншина и А.Л. Яншин отмечают [29, с. 246]: «На труды В.И. Вернадского по этой проблеме не была опубликована ни одна положительная рецензия». Зато отрицательных было более чем достаточно. В.И. Вернадский обвинялся в идеализме, не диалектическом подходе к проблемам науки и геологии, в частности антиматериалистических взглядах на природу и просто в ошибочной интерпретации фактических данных. Сведения о роли живого вещества в геологических процессах просто игнорировались.

Так, в трехтомной монографии Н.М. Страхова «Основы теории литогенеза» [21] и в книге «Типы литогенеза и их эволюция в истории Земли» [22] нет ни одной ссылки на В.И. Вернадского, хотя многие проблемы седиментогенеза рассмотрены им достаточно подробно. В 1971 г. в работе «Развитие литогенетических идей в России и СССР» [23] Н.М. Страхов пишет, что биогеохимическая концепция (основа учения о биосфере) достигла апогея, «когда к ней присоединился В.И. Вернадский» [23, с. 314]. «Сейчас мы знаем, что эта идея - плод крайнего увлечения биогеохимией; она не реализована до сих пор, и мало надежды на ее реализацию вообще». «Присоединение к биогеохимической концепции стало носить признаки шаблона - с неизбежной при этом вульгаризацией представлений» [23, с. 315]. Вполне очевидно, что биогеохимические седиментационные идеи противоречили представлениям Н.М. Страхова, который свел все процессы лито- и диагенеза к физико-химическим процессам без участия биоса.

Из всего учения о биосфере Н.М. Страхов выделил только одну идею: «особенно важной и плодотворной оказалась идея В.И. Вернадского о биогенном происхождении кислорода» [23, с. 314]. Однако это не совсем точная формулировка идеи. Забегая вперед, отметим, что В.И. Вернадский писал о стабилизации содержания кислорода в атмосфере (и гидросфере) биосом, первичный генезис которого мог быть совершенно другим.

Иная реакция была за рубежом. В.И. Вернадский имел возможность пропагандировать свои воззрения, выступая с докладами на собраниях научных обществ Франции, Англии, Германии. Идеи исследователя о проблемах биосферного окружения Земли вызывали живейший интерес и, более того, требовали активных действий в аспекте анализа влияния человека на состояние биосферы и ее сохранения.

Последнее обстоятельство способствовало созданию ряда общественных и научных организаций и даже партий, объединенных решением одной задачи - защитой окружающей среды. По их инициативе под эгидой ЮНЕСКО в 1972 г. в Стокгольме состоялась первая Международная конференция по охране окружающей среды, на которой была принята программа «Человек и биосфера» [26]. Действие этой программы охватывает чрезвычайно широкий круг вопросов: в соответствии с ее основными положениями создаются биосферные заповедники, государственные и международные природоохранные органы. Это принципиально новое воззрение человечества на окружающую нас среду нашло отражение во многих международных конвенциях.

В частности, Украина, присоединившись к Международной конвенции по морскому праву [25], взяла на себя определенные обязательства, в соответствии с которыми «Прибрежные государства должны принимать законы и правила для предотвращения сокращения и сохранения под контролем 
загрязненной морской среды, вызываемого или связанного с деятельностью на морском дне, попадающем под их юрисдикцию, и искусственными островами, установками и сооружениями» (ст. 208, п. 1) [25]. При этом, «Национальные законы, правила и меры должны быть не менее эффективными в предотвращении, сокращении и сохранении под контролем такого загрязнения, чем глобальные нормы и стандарты» (ст. 210, §6) [25].

В этом же аспекте необходимо отметить решения Международной конференции по климату планеты, состоявшейся в Киото (Япония) в декабре 2000 г. В результате работы конференции был принят Киотский протокол, согласно которому страны, его подписавшие, должны сократить выбросы углекислого газа, а также других «парниковых» составляющих атмосферы с целью исключения антропогенного вмешательства в климатические вариации. Украина подписала и ратифицировала решения Киотского протокола.

Как видно из приведенных примеров взгляды В.И. Вернадского на биосферу и переход ее в новое качество под влиянием деятельности человека - в ноосферу трансформировались в понимание необходимости сохранения окружающей среды, воспринимаются современными исследователями как давно известная истина.

Однако концептуальная постановка проблемы о роли биосферы в геологических процессах сохранилась. Ряд идей требуют более глубокого анализа, особенно в свете новых данных, полученных морскими геологами в последние годы. К таким идеям относятся воззрения В.И. Вернадского о том, что в геологический период существования Земли газовый состав атмосферы относительно стабилен, атмосферные газы преимущественно биогенного происхождения, климатические условия меняются в крайне незначительных пределах, биомасса живого вещества постоянна. Эти, на первый взгляд парадоксальные положения, связаны В.И. Вернадским в единый комплекс действия биосферных факторов, исходя из тех данных, которыми можно было оперировать в годы написания книги.

Даже А.П. Виноградов, ученик и последователь В.И. Вернадского, в редакционной статье к пятому тому избранных сочинений В.И. Вернадского отмечает, что с некоторыми утверждениями В.И. Вернадского нельзя согласиться, например «о постоянстве массы живого вещества на Земле в течение всей геологической истории» [6, с. 3].

Тем не менее этот тезис неоднократно повторяется: «Количество жизни на земной поверхности неизменно в геологические периоды (от архея до настоящего времени)» [6, с. 46]; «количество живого вещества остается незыблемым в течение всего геологического времени», [6, с. 47]; «неизменность массы протоплазматических образований в биосфере в течение геологических периодов» [6, с. 48].

Этот, наиболее спорный вывод, который, на первый взгляд, находился в противоречии с результатами палеобиологических исследований, В.И. Вернадский обосновывал, исходя из анализа развития «пленки жизни»: скорости размножения организмов различного уровня развития, темпов их распространения на поверхности Земли, интенсивности обменных процессов живого вещества с окружающей средой.

Наиболее активным компонентом живого вещества планеты являются бактерии, одноклеточные растительные организмы, размножающиеся делением. Скорость их размножения максимальна. Бактерии обладают «максимальной для живого вещества кинетической, геохимической энергией» [6, c. 93].

По расчетам В.И. Вернадского, заселение поверхности Земли микрофлорой Vibrio cholerae coставляет 1,25 суток, планктоном - 168-183 суток, суточный прирост клеток достигает значений $(2,2-6,4) \cdot 10^{18}[5$, с. 317]. Отметим, что современными исследованиями эти расчеты подтверждаются.

Размеры бактерий n·10-4 - n·10-6 см и масса единичных индивидуумов крайне незначительны, но их количество в процессе размножения растет в геометрической прогрессии, что создает в совокупности за весьма краткий промежуток времени огромную биомассу. Эквивалент, которой более высокоорганизованное живое вещество, может накопить за десятки - сотни лет.

Возможно, что в процессе создания первичной биомассы определенную роль играют вирусы, бактериофаги, субмелкая неклеточная форма жизни. Так, относительно крупный вирус табачной мозаики в поперечнике имеет размеры $15 \cdot 10^{8}$ до $300 \cdot 10^{8} \mathrm{~cm}$ по длине. Число атомов в молекуле этого вируса составляет 5·106. Вирус ящура имеет сферическую форму в диаметре до $20 \cdot 10^{8}$ см и содержит $70 \cdot 10^{3}$ количество атомов. Еще более мелкие размеры имеют бактериофаги - вирусы, патогенные для бактерий. Обычно округлой формы с хвостовым отростком. Размеры их варьируют от 0,4·10 
до 90.108 см. Формы - шаровидные, призматические, нитевидные. Призматические и цилиндрические имеют отросток в виде хвостика. В оболочку цилиндрических форм упакован спиральный фрагмент белковой молекулы. При выделении из несущей матрицы и обезвоживании образуют паракристаллы, которые могут существовать весьма длительный промежуток времени и сохранять свойства живой органики пока сохраняется их кристаллическая структура.

Бактериофаги обнаружены для всех видов бактерий. Предполагалось, что они отличаются строгой специфичностью и не могут существовать без «хозяина». Но исследования последних лет показали, что вирусы активно мутируют в зависимости от конкретных условий обитания. Роль вирусов в формировании биосферы совершенно не изучена, но вполне вероятно, что вирусы являются ограничительным фактором в безудержном развитии бактериальной биомассы.

Распространение бактериальной микрофлоры (и в целом - всей живой органики) и производимой биомассы ограничивается главным образом наличием в достаточных количествах веществ, используемых в трофических цепях организмов, т.е. продуктов питания. «В мире организмов в биосфере идет жесточайшая борьба за существование - не только за пищу, но и нужный газ, и эта последняя борьба более основная, так как она нормирует размножение» [6, с. 35]. «Кругом идет между живыми существами, неподвижными растениями жестокая борьба за существование, ... прежде всего борьба за газ, за дыхание». [4, с. 304].

По В.И. Вернадскому газовый обмен организмов - их дыхание, главная часть механизма биосферы [4, с. 49]. «Одним из важнейших проявлений жизни, имеющих огромное значение в биосфере, является газовый обмен организмов с окружающей средой» [6, с. 48]. Биогеохимическая энергия роста и размножения - следствие газового обмена живого вещества, биомасса которого определяется количеством биологически активных веществ, используемых в трофических цепях организмов различного уровня развития. Прежде всего - биологически активных газов, в том числе диоксида углерода, первичным и наиболее активным потребителем которого является бактериальная микрофлора и растительность.

Таким образом, можно сделать вполне обоснованный вывод, что масса живого вещества определяется главным образом массой газовой компонентой атмосферы и гидросферы; причем состав атмосферы и газовый режим океана находятся в тесной взаимосвязи, обуславливая их квазистационарное состояние.

Отметим, что трофические цепи бактериальной микрофлорой не ограничиваются только газами. С.И. Виноградский еще в конце прошлого столетия [7] открыл способность нитрифицирующих и некоторых других видов бактерий окислять неорганические соединения и использовать выделяющуюся при окислении неорганических веществ энергию на усвоение углекислоты, марганца, железа для построения своего тела. Трудами многих исследователей в последующие годы такой способ усвоения и концентрации вещества и перевода его в нерастворимые или трудно растворимые соединения был выявлен у силиконовых, сульфатредуцирующих, метанокисляющих и других бактерий, а также и грибковых организмов.

Кроме того, как показал Г.А. Заварзин [12, 13], авто- или литотрофные (по Г.А. Заварзину), бактерии, кроме способности накапливать в своей оболочке минеральное вещество, создают на своей поверхности условия, способствующие его осаждению. Не отрицая роли физико-химических процессов в накоплении рудного вещества, Г.А. Заварзин полагает, что этот процесс может происходить и без бактерий, но только скорость его протекания в этом случае будет многократно меньше. Эту особенность формирования скоплений марганца в современных условиях отметил В.Ф. Чухров [27, 28].

Однако, во всех этих процессах используется газ. Поэтому утверждение В.И. Вернадского: «Среда, лишенная газов, не может являться областью жизни» [6, с. 35], вполне обосновано.

Формирование атмо- и гидросферы, согласно наиболее признанной гипотезе А.П. Виноградова [8], связывается с процессами дегазации глубинных недр Земли, прежде всего пород мантии. По представлениям В.А. Рудника и Э.В. Собботовича [19], атмо- и гидросфера формировались одновременно вместе с земной корой вследствие дегазации протокоры и закончились примерно 4 млрд лет назад. Легкие газы (в том числе $\mathrm{H}_{2} \mathrm{O}$ и $\left.\mathrm{CH}_{4}\right)$ диссипировали, тяжелые $\left(\mathrm{CO}_{2}, \mathrm{CO}, \mathrm{NOH}\right.$ ) оставались в поле притяжения Земли. На заключительном этапе аккреции Земли включились в «работу» магматические процессы и началось накопление газов в атмосфере, создав определенный экран процессам диссипации. 
Таким образом, на начальных этапах развития Земли компонентный состав атмосферы мог меняться в значительных пределах (метановая, углекислотная, азотная атмосферы), но кислород в первичной атмосфере, по мнению многих исследователей, отсутствовал. Это вряд ли соответствует действительности, так как наличие кислорода в составе атмосферы связано не только с процессами дегазации глубинных горизонтов, в том числе и мантии, но и диссоциацией паров воды, которая сопутствует любым магматическим процессам и присутствует в составе практически всех видов изверженных пород.

Пары воды не были инертной составляющей атмосферы, а активно реагировали на ультрафиолетовое излучение Солнца, разлагаясь на кислород и водород. Наиболее интенсивно процесс фотодиссоциации начался при появлении зеркала воды на поверхности Земли. Время появления жидкой фазы воды на поверхности Земли можно определить по времени начала формирования пород аквального осадочного комплекса. Наиболее древние осадочно-вулканогенные образования, содержащие хорошо окатанную гальку и валуны, обнаружены в юго-западной Гренландии (район Амитсок), возраст которых определен в 3760 млн лет [1]. Г.И. Каляев показал, что железистые кварциты района Исуа ассоциируются с амфиболитами, гранитогнейсами Амитсок вследствие «магматического замещения океанской коры в первичных островных дугах». Отметим, что накопление железа в древних железистых кварцитах связано с деятельностью бактерий в мелководных морских бассейнах [16].

Следовательно, уже 4 млрд лет назад существовал водный бассейн. С образованием зеркала воды вследствие фотодиссоциации, согласно расчетам Э. Бютнер, содержание кислорода в атмосфере за 30 млн. лет может достичь 20\% [18].

Однако Э. Бютнер не указывает на два важных обстоятельства: 1) какова первичная плотность атмосферы в момент появления водного зеркала и 2) на какую площадь водной поверхности воздействовало солнечное излучение. Мы провели несколько вариантов аналогичных расчетов, предполагая, весьма условно, что в крайнем случае плотность первичной атмосферы, темп процессов фотодиссоциации и активность солнечного излучения примерно соответствуют современным параметрам. Именно в этом крайнем случае оказалось, что водной поверхности Черного моря вполне достаточно для 20\% насыщения атмосферы кислородом всего за 10 млн лет.

Содержание кислорода и углекислого газа в атмо- и гидросфере было всегда взаимосвязано и между ними устанавливалось определенное динамическое равновесие, которое стабилизировалось после появления биосферы.

По представлениям Ю.П. Казанского, «количество растворенного в морской воде $\mathrm{CO}_{2}$ древних морских бассейнов было того же порядка, что и в современном океане» [15, с. 13]. Поэтому существует вполне обоснованное мнение, что состав атмосферы и гидрохимический режим океанов существенно не менялся, по крайней мере за последние 500 млн лет состав атмо- и гидросферы не испытывал существенных изменений и мало отличался от нынешнего. Состав газов «количественно неизменен в ходе геологического времени» [4, с. 238] от момента появления жизни на Земле до настоящего времени.

При такой оценке геохимических параметров атмо- и гидросферы, остававшихся практически неизменными со дня появления органической жизни на Земле, заключение В.И. Вернадского, что биомасса Земли является величиной конечной и строго определенной, не кажется столь парадоксальным. Количество живого вещества в любой экологической системе определяется темпом его развития, наличием жизнеобеспечивающих биологически активных компонентов и является результатом функциони-рования взаимосвязанных процессов фотосинтеза и дыхания.

Это положение может быть выражено следующей формулой:

\section{М биомасса $\cdot$ K1 = М биогены $\cdot$ К2}

Где К1 - коэффициент пропорциональности, учитывающий особенности живого вещества; К2 - коэффициент, учитывающий наличие и виды биологически активного минерального вещества.

Из этой формулы следует, что отношение биомассы к жизнеобеспечивающим биологически активным компонентам есть величина постоянная:

\section{М биомасса: $\mathrm{M}$ биогены = Const.}

Это положение нашло подтверждение в исследованиях В.Е. Закруткина проблемы формирования древнейших карбонатных пород и роли живого вещества в этом процессе [14]. Он показал, что если скорость фотосинтеза в первом приближении пропорциональ-на концентрации $\mathrm{CO}_{2}$, то ско- 
рость образования чистой продукции [10] в мировом масштабе, а следовательно, и биомасса пропорциональны концентрации углекислого газа.

Создание биомассы выводит из оборота огромное количество биологически активных компонентов среды, прежде всего газов, причем темп их извлечения очень высокий. А.П. Виноградов [8] полагает, что содержание $\mathrm{CO}_{2}$ в атмо- и гидросфере определяется деятельностью биоса в последние 2,5-3,5 млрд лет. Расчеты динамики биосферных процессов показали полное время пребывания $\mathrm{CO}_{2}$ в атмосфере около 5 лет, фотосинтезирующие растения оборачивают примерно весь кислород атмосферы в 2000-3000 лет; $\mathrm{CO}_{2}$ в океане (при современном его содержании) - в 350-500 лет, а вся вода океана проходит через фотосинтезирующие растения в течение нескольких миллионов лет. Это значит, что биосфера стала одной из динамичных оболочек земного шара.

Новые расчеты времени пребывания углерода и его массообмене между разными углеродными резервуарами, основанными на радиоуглеродных исследованиях, выполнены P.E. Damon, J.C. Lerman, A. Long [31]. Отметим, что в качестве самостоятельного углеродного резервуара авторы работы выделяют биосферу.

\begin{tabular}{|c|c|c|c|}
\hline Резервуар & $\begin{array}{c}\text { Количество C в } \\
\text { резервуаре, n.10 }\end{array}$ & Поток C, n·10 ${ }^{15}$ г/год & Время пребывания \\
\hline Атмосфера & 670 & 156 & 4 года \\
\hline Биосфера суши & 550 & 56 & 10 лет \\
\hline Гумус & 1050 & 56 & 19 лет \\
\hline Гидросфера суши & 449 & 0,37 & 1213 лет \\
\hline Поверхностный слой океана & 900 & 124 & 7 лет \\
\hline Глубинный океан & 36670 & 32 & 1180 лет \\
\hline Биосфера океана & 6 & 40 & 2 месяца \\
\hline Мертвое органическое вещество в & 3000 & 40 & 75 лет \\
\hline океане & 90000000 & 0,6 & 150 млн лет \\
\hline Донные осадки & & & \\
\hline
\end{tabular}

Пополнение углеродного резерва атмо- и гидросферы должно происходить непрерывно. В.И. Вернадский в этом вопросе придавал решающее значение деятельности биосферы, обращая внимание на то, что между атмо- и биосферой существует тесная связь, выражающаяся в том, что четыре основные компонента биосферы из пяти - водород, кислород, углерод, азот и кальций, представлены среди пяти главных элементов атмосферы: азот, кислород, водород, углерод, аргон. Угольная кислота - основной биогенный продукт на нашей планете. Метан и аммиак на нашей Земле всегда биогенные [4, с. 29]. «В результате - жизнь - живое вещество создает тропосферу и непрерывно ее в динамическом равновесии поддерживает около некоторого статического равновесия» [4, с. 239].

В.И. Вернадский не исключал поступление газов в атмосферу вследствие дегазации глубинных горизонтов Земли - газового дыхания планеты, космических явлений, но при этом подчеркивал, что живое вещество удерживает состав атмосферы в ее динамическом равновесии [6, с. 215]. «Мы имеем дело с неизменно существующими в течение геологического времени динамическими равновесиями» $[4$, с. 215].

Это динамическое равновесие обусловлено деятельностью «пленки жизни» [21], через которую «прокачиваются» все компоненты атмосферы, морские и океанические воды, чутко реагируя на любые изменения в их составе и выводя из оборота «избыточные» компоненты. В этом проявляется мощная буферная деятельность биоса, его регулирующая и стабилизирующая роль в круговороте ве-щества в природе.

Необходимо отметить, что сведения о биомассе планеты, количественных характеристиках процессов дегазации крайне противоречивы. Так, В.И. Виноградов [9] полагает: «Дегазация Земли и формирование ее газоводной оболочки закончилось на самых ранних этапах существования планеты. 
Поэтому сегодня или совсем не обнаруживаются признаки продолжающейся дегазации мантии или обнаруживаются в некоторых случаях признаки ее ничтожной дегазации. В основном в составе современных термопроявлений участвует вещество, которое находится в циклическом круговороте в пределах поверхностных оболочек земной коры». По мнению автора, круговорот углерода происходит по схеме: «органическое вещество - карбонаты через $\mathrm{CO}_{2}$ атмосферы и фотосинтез». После открытия глубоководных газовых, газогидротермальных источников эта точка зрения вряд ли оправдана.

Кроме того, в прежних балансовых расчетах биомассы планеты не учитывались такие формы, как наннопланктон, бактериальная микрофлора, фауна и флора глубоководных зон Мирового океана. Так, потоки эндогенного метана, поступающие в водную толщу, используются газ как объект питания метанокисляющими бактериями. Последние накапливаются на поверхности ложа океана в непосредственной близости от газовыделяющих структур - газовых курильщиков и формируют на огромных площадях бактериальные маты толщиной до 30 см и более. Эти маты являются первичным продуктом биохемосинтеза органического вещества, в составе которых обнаружены различные аминокислоты, сахара, белки и различные углеводы и используются в трофических цепях гетеротрофных организмов, включая плазмоидные организмы. Массу их пока определить не представляется возможным.

Как полагает Н.П. Семененко, метан образуется в глубинных горизонтах нижней мантии при отсутствии кислорода. В виде газовой компоненты поступает в атмосферу во время вулканических извержений, участвует в магматических процессах и, очевидно, является начальным звеном в образовании абиогенных углеводородных соединений. Последнее, доказывается прямыми исследованиями наличия углеводородов и газовых включений в базальтах. Как было установлено ранее, количество углеводородов варьирует в очень широких пределах - от 0 до 250 мг на 1 кг исследуемой породы, при этом в составе абиогенной органики преобладают парафины, присутствуют аминокислоты.

Существует точка зрения, что в настоящее время наблюдается определенный дефицит диоксида углерода в атмосфере, что сказывается на развитие растительной органики. «Сегодня все зелёные растения вынуждены работать на голодном углекислотном пайке, так как нынешнее содержание $\mathrm{CO} 2$ менее благоприятно для фотосинтеза» [8]. Такую точку зрения можно рассматривать как альтернативную гипотезе антропогенного влияния на состав атмосферы.

В этом аспекте была сделана попытка рассчитать баланс диоксида углерода в атмо- и гидросфере с учетом новых данных, полученных в морских экспедициях Института геологических наук НАН Украины [11], и оценки влияния антропогенных факторов на климат. Было установлено, что изменения климата связаны с гораздо более значимыми явлениями, чем антропогенные выбросы парниковых газов.

Климатические изменения В.И. Вернадский связывал с геологической историей нашей планеты: «есть времена большей и меньшей интенсивности геологических процессов», которые он назвал «критическими периодами» [4, с. 48]. Что касается влияния на климат солнечной активности, то исследователь полагал, что «климатические, прежде всего тепловые условия биосферы, коренным образом никогда не менялись. Климат в своих астрономических тепловых основах оставался неподвижным» [4, с. 54]. Отметим, что по современным представлениям поток солнечной энергии на Землю за последние 3 млрд лет существенно не менялся, даже было введено понятие - Солнечная постоянная.

Однако физическое воздействие Солнца на электромагнитное и гравитационное поля Земли, несомненно, и связано с взаимным расположением планеты и светила. Так, в апогее радиус земной орбиты на 5 млн км больше, чем в перигее, что, безусловно, влияет на энергетический потенциал взаимодействия Земля - Солнце.

Но наибольший эффект имеет положение Земли в крайних точках галактической орбиты. В.А. Рудник и Э.В. Собботович [19] рассчитали, что в перигалактии (в области, наиболее близкой к центру нашей галактики) гравитационный потенциал на 27\% выше, чем в апогалактии. Они полагают, что в настоящее время Земля уходит в область апогалактии и степень сжатия Земли уменьшается. Это обстоятельство способствует активизации и оживлению глубинных разломов и связанных с ними процессов глубинной дегазации.

В 1959 г. Г.П. Тамразян вычислил периодичность галактического года - примерно 200 млн лет. Эта периодичность совпадает в первом приближении с эпохами максимальной тектонической активности, орогенными фазами по Штилле. Определенные несовпадения в определении галактического года и эпох активизации связано с наложением влияния положения Земли относительно Солнца, взаимодействием с Луной и другими космическими факторами. Для нас важно отметить что эпохи 
тектономагматической активизации сопровождаются активизацией дегазации глубинных горизонтов Земли, в частности повышенными выделениями углекислого газа в атмосферу, достигающими 0,14.1017 т $\mathrm{CO}_{2}$ [8] за счет продуктов «холодной дегазации», которая, на наш взгляд, является более широко распространенным процессом, чем гидротермальные проявления. По мнению Н.Ф. Балуховского [2], именно сочетание указанных факторов определили цикличность и ритмичность в осадконакоплении и климатические вариации.

Обладая определенной инертностью, биосфера не может немедленно (в геологическом масштабе времени) реагировать на изменение геохимических параметров атмосферы. Вполне очевидно, что если темп поступлений $\mathrm{CO}_{2}$ превышает темп его потребления, то начинает сказываться парниковый эффект, приводящий к эффекту глобального потепления. В результате глобального потепления активно проявляется неустойчивость атмосферной системы, в частности резкие перепады давления способствуют возникновению сильных ветров, турбуленции воздушной массы и т.д.

Реакция флоры и фауны на изменение гидрохимического режима океана и геохимического атмосферы происходит по пути увеличения (или уменьшения) биомассы при сохранении основных геохимических параметров внешних оболочек Земли, включая и верхние горизонты литосферы.

Одновременно меняются фаунистические и флористические комплексы. Так, уменьшение поступлений диоксида углерода $\mathrm{CO}_{2}$ сопровождается глобальным понижением температуры атмосферы, что приводит к сокращению растительной массы - основы питания травоядных ящеров. Следствие этого - сокращение популяции указанного вида животных и их полное вымирание: одновременно вымирают и хищные ящеры. Развивается растительный покров, более приспособленный к уменьшению темпов поступлений гипогенного $\mathrm{CO}_{2}$, одновременно наблюдается эволюционное развитие организмов, менее подверженных влиянию температурных изменений - теплокровных. Остатки теплолюбивых форм деградируют в размерах и сохраняются как эндемичные организмы в достаточно изолированных наиболее приспособленных для их жизни участках Земли. Примером потомков древнейших звероящеров являются вараны о-ва Комодо, крокодилы.

Парниковый эффект приводит к значительному расширению площадей развития растительной жизни. По мере увеличения базы питания растет количество и размер растительноядных животныхи соответственно - количество и размер хищников.

Предполагается, что в меловое время содержание в атмосфере $\mathrm{CO}_{2}$ было на порядок выше современного. Этим можно объяснить факт развития теплолюбивых форм растительности в Антарктиде и Шпицбергене, а площадь развития биогенных осадков только в Европе и частично Азии составляет более 40 млн км². Следует добавить, что биогенными породами позднего мела перекрыта значительная часть Китая, Северной Африки, Америки и шельфовые зоны Атлантического океана.

Океаническая фауна более консервативна и реагирует на изменения гидрохимических параметров водных толщ главным образом изменением видовых форм простейших.

Некоторые модальные расчеты [31, с. 267] показывают, что удвоение содержания диоксида углерода может привести к повышению глобальной температуры на 2-3드. но в полярных областях этот рост может быть существенно выше. В то же время имеются данные, что возрастание $\mathrm{CO}_{2}$ на $10 \%$ приводит к эффекту глобального потепления на $0,5^{\circ} \mathrm{C}$. Ожидаемое увеличение концентрации $\mathrm{CO}_{2}$ в атмосфере к 2030 г. может возрасти на 50\% вследствие сжигания топлива, что приведет к потеплению до $2,5^{\circ} \mathrm{C}$.

Палеотемпературные определения показали, что в позднем мелу температура поверхностных вод в пределах Черноморско-Кавказского региона достигала $+28^{\circ} \mathrm{C}$. Современная средняя температура равна $+12^{\circ} \mathrm{C}$. Разницу в $160 \mathrm{C}$ может обеспечить повышение содержания СО2 на $16-20 \%$ или до 0,0316-0,320\%, но никак не десятки и единицы процентов.

Отметим, что атмосферное содержание $\mathrm{CO}_{2}$ составляет всего 0,03\%. Изменение его количества на $1 \%$, т.е. до 0,0303\%, определить весьма затруднительно, так как точность измерений содержаний газов в атмосфере лежит в пределах третьего знака и не превышает $\pm 0,005 \%$. Иными словами, изменение параметра находится ниже точности определений на целый порядок. Из приведенного следует, что результаты многочисленных замеров, часто противоречивые, требуют весьма осторожного отношения, так как позволяют с высокой точностью получить ошибочные результаты.

Таким образом, можно говорить о метастабильных параметрах водных толщ и атмосферы, допуская возможность их вариаций в определенных пределах, которые обусловлены активностью 


\section{В.X. ГЕВОРКЬЯН}

деятельности биоса и его массой. Однако эти пределы оценить в настоящее время весьма затруднительно.

Еще раз подчеркнем: интенсивность буферной деятельности биоса приводит к увеличению или уменьшению биомассы в зависимости от интенсивности поступления избыточных (недостающих) биологически активных компонентов глубинных флюидов, используемых в трофических цепях организмов.

Кроме диоксида углерода, в составе глубинных газов отметим, метан, сероводород, газообразные соединения азота. В виде растворов поступают соединения железа, марганца, фосфора, серы и другие элементы. Первичным консументом минерального вещества является бактериальная микрофлора. Бактерии обладают «максимальной для живого вещества кинетической, геохимической энергией» [6, с. 93].

Огромная геохимическая энергия бактерий [6, с. 86] выражается в использовании в своих трофических цепях неорганических соединений в качестве объекта питания, создании первичной биомассы, формировании скоплений рудного вещества, зон повышенной биологической продуктивности на различных глубинах океанического ложа, включая его глубоководные зоны вне пределов фотического слоя.

Таким образом, биос во всем своем многообразии является мощным фактором в извлечении ряда компонентов из океанических вод и атмосферы, осуществляя концентрационную функцию живого вещества первого рода - «захват тех элементов, которые составляют тело и ткани животныхи растений».

Иную позицию в этом вопросе занимает Н.М. Страхов. Он не признавал идей В.И. Вернадского о решающей роли биоса в жизни Земли, в том числе и осадкообразовании. Показательно, что в книге «Типы литогенеза и их эволюция в истории Земли» [6] нет ни одной ссылки на работы В.И. Вернадского. Климатически зональная теория литогенеза Н.М. Страхова [21] фактически полностью отрицает роль биогеохимических процессов в осадкообразовании и осадконакоплении. Критикуя эту концепцию, возникшую на основании изучения современных морских осадков Н.И. Андрусовым, Г.А. Надсоном, Я.В. Самойловым, Н.М. Страхов пишет: «Я.В. Самойлов [20] продолжал пропагандировать мысль о возникновении осадочных концентраций элементов в осадочных породах путем прямого экстрагирования этих элементов из морской воды специфическими группами организмов... Сейчас мы знаем, что эта идея - плод крайнего увлечения биогеохимией; она не реализована до сих пор, и мало надежды на ее реализацию вообще... Присоединение к биогеохимической концепции стало носить признаки применения шаблона - с неизбежной при этом вульгаризации представлений» [23, с. 315]. Н.М. Страхов полагал, что развитие ее достигло апогея, когда к ней присоединился в 20-х годах прошлого века В.И. Вернадский.

Отметим, что на роль биохимических процессов в осадкообразовании и концентрировании рудных компонентов биосом В.И. Вернадский указывал задолго до создания цельной концепции еще в начале XX в. после открытия В.С. Виноградским (1952) способности бактерий осаждать железо.

Развитие теоретических представлений В.И. Вернадского в литологии привели к открытию нового типа литогенеза - наложенного. Наложенный литогенез определяется процессами дегазации мантии, поставками в верхние слои литосферы, гидросферу и атмосферу эндогенных флюидов и их трансформации в астадиальные и аседиментационные образования, не связанные с осаждением вещества из водных растворов и изменениями в диагенезе, а обусловленные деятельностью биоса.

В качестве примера укажем на современные железомарганцевые и кобальт-марганцевые корки, обнаружен-ные нами еще в 1972 г. корки чрезвычайно прочные, сливной текстуры, толщина их достигает 20-30 см. Развиты они главным образом в пределах подводных гор и поднятий, т. е. приурочены к зонам тектонических нарушений, которые служат проводниками глубинного вещества. Темп железомарганцевой минерализации определялся на основании возраста остатков кораллов, заключенных в железомарганцевую корку толщиной до 15 см. Кораллы находятся в основании корки в пятисантиметровом слое, не прерывают ее, т.е. являются замкнутой системой. Их возраст по углеродно-

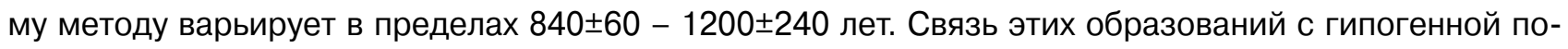
ставкой рудного вещества была вполне зримой и контролировалась не только приуроченностью их к по-верхности скальных пород или осадка в виде корок, но и скоростями такой минерализации, достигавшей значений десятки см. за тысячу лет. Скорость формирования гидротермальной рудной 
марганцевой корки в рифтовых зонах при температуре гидротермальных источников 300оС составляет 220 мм/106лет [17].

Обратим внимание на то, что процесс накопления марганца был прерывистым, так как корки имеют слоистую структуру, выраженную чередованием прослоев собственно марганца, преимущественно железистых с тонкими слоями современных фораминифер. Текстурно корки являются монолитными сливными образованиями, которые можно отнести к метаморфическим стадиям преобразования исходного вещества. Никаких гидрохимических аномалий в пределах развития полей железомарганцевых корок обнаружено не было.

К сожалению, приходится констатировать, что теоретическое наследие В.И. Вернадского в сфере давлеющего практицизма в геологии изучено крайне недостаточно. Это необходимо учесть при подготовке специалистов геологического профиля нового поколения.

1. Аллорт Я. Древние супракрустальные породы с возрастом свыше 3760 млн лет и ассоциирующие с ними полосчатые железистые кварциты, район Исуа, центральная часть западной Гренландии // Ранняя история Земли. - М.: Мир, 1980. - С. 188-201.

2. Балуховский Н.Ф. Геологические циклы - Киев: Наук. думка, 1966-168 с.

3. Бримклумб П. Состав и химия атмосферы - М.: Мир, 1988 - 352 c.

4. Вернадский В.И. Химическое строение биосферы Земли и ее окружения - М.: Наука, 1965 - 374 с.

5. Вернадский В.И. Биосфера. Л.: Науч. хим.-техн. издво, 1926 - 146 с.

6. Вернадский В.И. Избранные сочинения. Т. 5. - М.: Изд-во АН СССР, 1960. - 422 с.

7. Виноградский В.С. О железобактериях // Микробиология почв. - М.: Изд-во АН СССР, 1952. - С. 56.

8. Виноградов А.П. Введение в геохимию океана. - М.: Наука, 1967. - 216 с.

9. Виноградов В.И. Изотопный состав элементов и проблема дегазации мантии и формирование газоводной оболочки Земли // Дегазация Земли и геотектоника. - М.: Наука, 1980. - С. 23-30.

10. Вудвелл Дж. Круговорот энергии в биосфере. // Биосфера. М.: Мир, 1972. - С. 41-59.

11. Геворк'ян В.Х. Газовое дыхание планеты и баланс гиоксида углерода в атмосфере и гидросфере. // Геол.. журн. № 2. 2003. - С. 77-91.

12. Заварзин Г.А. Литотрофные микроорганизмы. - М.: Наука, 1972. - 324 с.

13. Заварзин Г.А. Бактерии и состав атмосферы. - М.: Наука, 1984. - 193 с.

14. Закруткин В.Е. О роли живого вещества в формировании древнейших карбонатных пород. В кн.: Проблемы осадочной геологии докембрия. - М., Наука, 1981. - С. 137-143.

15. Казанский Ю.П. Седиментология. - Новосибирск: Наука, 1976. - 272 с.

Institute of Geological Sciences NAS Ukraine, Kyiv, Ukraine Институт геологических наук НАН Украини, г. Киев, Украина
16. Лазуренко В.И. Геологическая деятельность железобактерий. - Киев: Наук. думка, 1989. - 92 с.

17. Лисицын А.П. Гидротермальные образования рифтовых зон океана. - М., Наука. 1990. 255 с.

18. Мухин Л.М. О тепловом углекислотном маятнике. // Химия и жизнь. - 1977. № 12. - С. 62-64.

19. Рудник В.А., Собботович Э.В. Ранняя история Земли. - М.: Недра, 1984. - 350 с.

20. Самойлов Я.В. Изучение известняков с палеофизиологической точки зрения // Изв. Моск. отд-ния Геол. ком. - 1923. - Т. 1. - С. 287-289.

21. Страхов Н.М. Основы теории литогенеза. Т. 1-3. - М.: Изд-во АН СССР, 1961-1962. Т. 1. - 212 с.; Т. 2. - 574 с.; T. 3. $-545 \mathrm{c}$.

22. Страхов Н.М. Типы литогенеза и их эволюция в истории Земли. М.: Госгеолтехиздат, 1963. - 536 с.

23. Страхов Н.М. Развитие литогенетических идей в России и СССР. - М.: Наука, 1971. - 624 с.

24. Тамразян Г.П. О периодических изменениях климата и некоторых вопросах палеогеографии // Сов. геология. - № 7. - 1959. - С. 140-149

25. Третья конференция по морскому праву. OOH./CONF/ 62/L. 76. 3. 28 августа 1981. -194 с.

26. Человек и биосфера. - Стокгольм, 1972.

27. Чухров В.Ф., Горшков А.И., Рудницкая Е.С. и др. Гипергенные окислы железа. - М.: Наука, 1975. - 206 с.

28. Чухров В.Ф., Горшков А.И., Рудницкая Е.С. и др. О вернадите // Изв. АН СССР. Сер. геол. - 1978. № 6. - С. 5-20.

20.Яншина Ф.Т., Яншин А.Л. Эволюция взглядов В.И. Вернадского на живое вещество и биосферу // Вестн. РАН. T. 70, № 3. - C. 243-248.

30. Vernadsky V. La Biosphere. - Paris: Alean. 1929. - 232 p.

31. Damon P.E., Lerman J.C., Long A. Temporal fluctuation of atmospheric !4C: causal factors and implication. Ann. Rev. Earth. Sci. - 1978. № 6. - P. 457-494. 